\title{
Unfortunately The Introduction Of Our New Product Will Be Delayed: An Exploratory Examination Of Factors That Influence A Firm To Announce Changes In Its New Product Plans \\ Kim E. Schatzel, University of Michigan-Dearborn Roger J. Calantone, Michigan State University Cornelia Droge, Michigan State University
}

\begin{abstract}
New product preannouncement research investigates formal and deliberate communications by a firm regarding its future new product introductions (e.g., types of new products, new product attributes, plans for distribution, planned launch date). However, previous studies have primarily focused on communication related to the firm's intent to introduce a new product and largely ignored communications regarding changes in their status, such as launch delays as well as cancellation of the new product introduction. The goal of this study is to address this shortfall by examining antecedents factors influencing a preannouncing firm (i.e., one that preannounces its new products) to also announce changes in to its new product introduction plans (NPCs); specifically, delays in the introduction of a new product or its cancellation. This topic is particularly relevant given the importance that recent studies have placed on the investigation of false new product preannouncements or bluffs, especially in the software industry where they are termed vaporware. Furthermore, in the wake of the many recent high-profile corporate scandals (e.g., Enron and Tyco), a growing emphasis on corporate disclosure, particularly regarding performance shortfalls (e.g., new product delays and cancellations), also highlights the need for further research on corporate communication regarding changes to new product introduction plans. Additionally, unlike most extant preannouncement research that attempts to examine differences between preannouncers and non-preannouncers, our study only examines firms that preannounce their new product introductions and then, goes further, by examining post-preannouncement behavior. In developing our framework, we propose five antecedents that motivate a preannouncing firm's propensity, when the situation arises, to issue announcements regarding delays in a new product introduction or its cancellation. Additionally, we highlight the use of NPCs as strategic marketing communication tools that can continually inform and influence a wide range of target audiences (e.g., buyers, employees, supply chain participants, investors, and business media). The hypotheses are tested via factor score regression with a sample of 221 U.S. - based manufacturers. Our findings indicate that it is not the firm's desire to communicate in a general sense through information sharing nor its concerns regarding competitors that motivates preannouncing firms to issue NPCs. Instead, the preannouncing firm's desire to build its reputation, the innovativeness of its industry, and the degree to which buyers must make substantial pre-purchase investments are the main drivers of communication regarding changes to its new product introduction plans. As a set, these findings are particularly interesting as they indicate that the preannouncing firm's desire to reduce uncertainty, often in its own favor, underlies its decision to issue NPCs.
\end{abstract}

\section{INTRODUCTION}

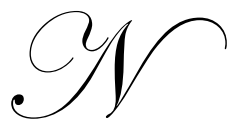

ew product preannouncement research (NPPs) (e.g., Calantone and Schatzel 2000; Chaney, Devinney, and Winer 1991; Eddy and Saunders 1980; Eliashberg and Robertson 1988; Farrell and Saloner 1986; Heil and Walters 1993; Lane and Jacobsen 1995; Lilly and Walters 1997; Rabino and Moore 1989; Robertson, Eliashberg, and Rymon, 1995, Schatzel, Calantone and Droge 2001; Schatzel, Droge, 
and Calantone 2003) investigates formal and deliberate communications by a firm regarding its future new product introductions (e.g., types of new products, new product attributes, plans for distribution, planned launch date). Extant research largely considers NPPs as beneficial tools that can reduce buyer uncertainty and switching costs, impact market influencers (e.g., industry experts and observers), encourage standardization, preempt competitor action and favorable influence general opinion regarding the company and its products. However, previous studies have primarily focused on communication related to the firm's intent to introduce a new product and largely ignored communications regarding changes in their status, such as launch delays as well as cancellation of the new product introduction.

The goal of this study is to address this shortfall by examining antecedents factors influencing a preannouncing firm (i.e., one that preannounces its new products) to also announce changes in to its new product introduction plans (NPCs); specifically, delays in the introduction of a new product or its cancellation. This topic is particularly relevant given that recent studies have emphasized further investigation of false new product preannouncements or bluffs, especially in the software industry where they are termed vaporware (see Bayus, Jain, and Rao 2001; Pradhu and Stewart 2001).

Furthermore, in the wake of the many recent high-profile corporate scandals (e.g., Enron and Tyco), a growing emphasis on corporate disclosure, particularly regarding performance shortfalls (e.g., new product delays and cancellations), also highlights the need for further research on corporate communication regarding changes to new product introduction plans.

Additionally, unlike most extant preannouncement research (e.g., Eliashberg and Robertson 1988; Schatzel, Calantone, Droge 2001), that attempts to examine differences between preannouncers and non-preannouncers, our study only examines firms that preannounce their new product introductions and then, goes further, by examining post-preannouncement behavior.

In developing our framework, we propose five antecedents that motivate a preannouncing firm's propensity, when the situation arises, to issue announcements regarding delays in a new product introduction or its cancellation. Additionally, we highlight the use of NPCs as strategic marketing communication tools that can continually inform and influence a wide range of target audiences (e.g., buyers, employees, supply chain participants, investors, and business media). Two of the antecedents are firm-specific and focus on the possible influences of organizational tendencies and strategy selection on a firm's propensity to issue NPCs. The two constructs are: (1) firm information sharing, which attempts to tap the firm's behavioral bias regarding sharing information with its stakeholders (e.g., buyers, employees, investors, supply chain and (2) the firm's pursuit of a high profile leadership position within its industry which we term reputation building. Within the context of the proposed framework, we also investigate the effects of two environmental antecedents, industry innovation and competitive hostility. The effect of buyer involvement as a possible motivator is examined as well.

After briefly discussing the use of NPPs and NPCs as strategic marketing communication tools, the framework and its hypotheses are developed. Next, the hypotheses are tested via factor score regression with a sample of 221 U.S. - based manufacturers. Next, the results are presented and, we conclude, by discussing the study's implications, as well as, its limitations.

\section{THE USE OF NPPs AND NPCs}

NPPs and NPCs, as compared to traditional advertising, are relatively quick and inexpensive for the firm to produce and thus provide the firm with an efficient and timely means of communication to various industry constituents regarding the firm's new product introduction plans (Calantone and Schatzel 2000; Schatzel, Droge, and Calantone 2003). They are often issued in press release form, "posted" to numerous news wire services as well as the firm's own internet site, and can be picked up and reported by various trade and general business media sources (e.g, Wall Street Journal, Automotive News, CNBC). 
Firms use NPCs to communicate changes in their new product introduction plans. NPCs can provide updates concerning the new product introduction such as changes in its timing, market availability of the new product, new product attributes, as well as, plans for its distribution. NPCs also provide management with a forum to explain or "spin" these changes, which is particularly germane when the new product introduction is cancelled or delayed For example, via NPCs, the firm can "explain" that the cancellation or delay was caused by factors such as the incorporation of additional new product features or the de-emphasis of a particular market segment. Thus, NPCs provide the firm with an opportunity to potentially mitigate any negative responses from stakeholders (e.g., investors, supply chain partners, buyers) resulting from these status changes In short, NPCs serve as low-cost strategic communications that enable the firm to update and influence targeted audiences (e.g, buyers, supply chain participants, investors) regarding changes to their new product plans.

\section{CONCEPTUAL FRAMEWORK}

The framework (Figure 1) has one dependent variable, a pre-announcing firm's propensity to issue NPCs, defined as its tendency to issue a formal communication announcing the delay or cancellation of a new product introduction.

In an attempt to better organize our discussion, we begin by presenting our hypotheses regarding the effect of the organizational antecedents on a preannouncing firm's propensity to issue NPCs. Next, we discuss the motivating influence of buyer involvement and, lastly, we present the hypotheses associated with the two environmental constructs - industry innovation and competitive hostility.

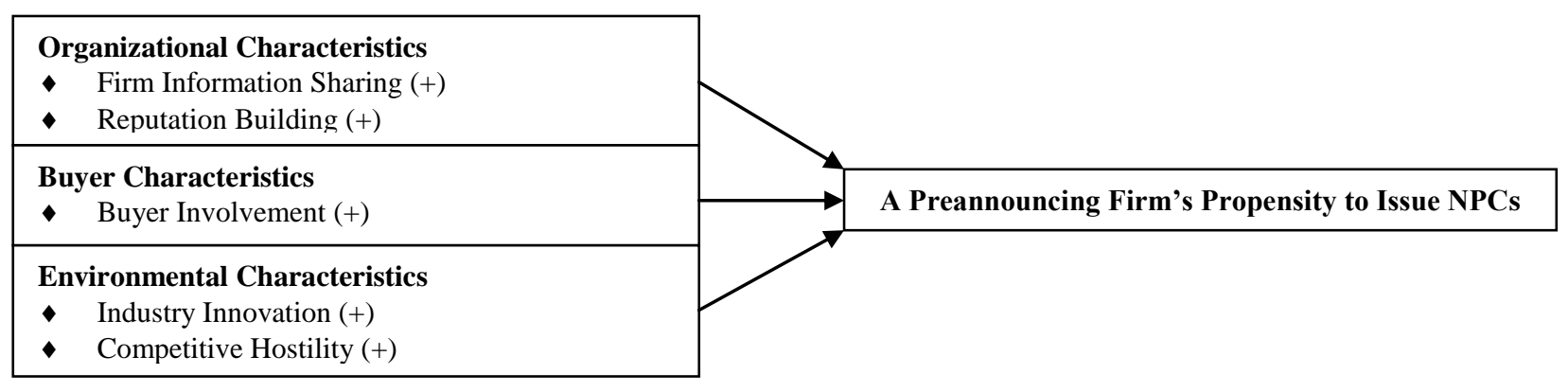

\section{Organizational Antecedents Of NPCs}

We define firm information sharing as the formal information exchange practices of a firm with a broad number of industry participants that are frequent, involved, and bi-directional in nature. This definition incorporates previous research that firms adopt proactive modes of communication, such that management influences the bounding of information exchange activities (El Sawy and Pauchant 1988; Pfeffer and Salanick 1978), as well as the notion that the information exchange is interactive; that is, the firm communicatively responds to the informational needs it identifies within its internal and external environment (e.g., updates on new product plans directed at the investment community, updates regarding entry into new geographic market segments in response to distributor queries, updates regarding plans for distribution partnerships aimed at sales personnel).

A firm with a greater degree of information sharing invests resources (both managerial and financial) to develop and maintain communication with its industry stakeholders (e.g., buyers, supply chain partners, investors, and business media). Such investments provide that the firm views information sharing as beneficial to firm performance.

Via NPCs, preannouncing firms can inexpensively and quickly respond to the informational needs of a wide range of target audiences (e.g., investors, buyers, supply chain partners). Press releases, management conferences and interviews can be tailored to meet their differing informational needs and ensure that these valued 
stakeholders are thoroughly informed in a timely manner of changes to the firm's new product introduction plans. Thus, we propose:

H1: Firm information sharing is related positively to a preannouncing firm's propensity to issue NPCs.

Extant literature indicates that firms often attempt to build a favorable reputation with key stakeholders such as buyers, supply chain partners, investors, industry experts and the business media (Kreps and Wilson, 1982; Rumelt, 1987; Spence, 1974; Weigelt and Camerer, 1988). Reputation can be a proxy for quality (Nelson, 1970, 1974), deter new entrants, provide for improved status as an industry influencing agent (Weigelt and Camerer, 1988), and even reduce a firm's marketing costs as compared to competitors (Milgrom and Robert, 1982).

Extant research provides that a firm's pursuit of a favorable reputation motivates their use of new product preannouncements (NPPs) (e.g., Calantone and Schatzel 2000; Eliashberg and Robertson 1988; Lilly and Walters 1997; Rabino and Moore 1989; Schatzel, Calantone, and Droge 2001). However, risks to the firm's reputation can occur if a preannounced planned action goes unfulfilled (Eliashberg and Robertson 1988; Heil and Robertson 1991). Given this possible outcome, we propose a preannouncing firm that emphasizes reputation building will also be motivated to issue NPCs as a means to explain their decision to cancel or delay a new product introduction and, thereby, mitigate possible negative effects the change could have on their reputation. Thus:

H2: Reputation building is related positively to a preannouncing firm's propensity to issue NPCs.

\section{The Motivating Effect Of Buyer Involvement}

Buyer involvement refers to conditions where the buyer's need for knowledge is a precursor to product trial and purchase. The need for knowledge can result from (Gatignon and Robertson, 1985): (1) buyer learning requirements that refer to a buyer's need to acquire information or skills to make use of the product, understand its function, or realize its benefits and, (2) innovation or switching costs that concern the incremental expenses, beyond the product, that result from its adoption. Such expenses can include obsolescence of an installed capital base and the required adoption of ancillary products such as in the case of product systems (e.g., computer software)

Involved buyers expend resources to acquire information regarding new products and often undertake significant preparation in anticipation of the new product (e.g., training for employees, conversion of existing programs and files prior to the purchase of a new computer system). Thus, changes to the new product's introduction timing or its cancellation will be particularly consequential for involved buyers as these preparation efforts and expenditures may have no or significantly reduced residual value. Additionally, as a result of the new product introduction cancellation or delay, the buyer may need to resume information search efforts regarding the new product and implement alternative preparation plans.

Through their issuance of NPCs, preannouncing firms can not only inform involved buyers of new product delays or cancellations and, thereby, minimize any extraordinary switching costs that may result, but they can also communicate the rationale for those changes and even provide the buyers with alternative product purchase scenarios to consider (e.g., An NPC regarding the planned cancellation of a new generation of optical gauging equipment with commentary detailing that some of the cancelled new product's key features will be incorporated into the current model in the near term). Thus, we propose:

H3: Buyer Involvement is related positively to a preannouncing firm's propensity to issue NPCs.

\section{Environmental Antecedents Of NPCs}

Innovative industry environments are characterized by frequent changes in marketing practices, products, and services (Miller and Friesen 1982). Firms in highly innovative industries emphasize R\&D and the development of new products and technologies. Often the new products are highly discontinuous innovations that leapfrog and obsolete existing technologies and products. 
Previous research indicates that environmental change, stemming from rapid, frequent, and discontinuous innovation, is a major factor in firm communication practices (Bourgeois and Eisenhardt 1988; Brown and Utterback 1985; Eisenhardt 1989). Innovative environments motivate the firm to communicate; that is, as changes to products and technologies becomes more frequent and bold, information exchange between the firm and the outside world will increase (Bourgeois and Eisenhardt 1988; El Sawy and Pauchant 1988; Gannon, Smith and Grimm 1992). A firm will be motivated to continually communicate its new product plans and their status to its industry constituents in an effort to respond their queries and maintain product awareness in response to its competitors' similarly aggressive new product strategies and tactics.

Through NPCs, the preannouncing firm can reduce uncertainty, a major characteristic of innovative industries, and thoroughly explicate its new product intentions (Eliashberg and Robertson 1998, Lilly and Walters 1997, Rabino and Moore 1989) and, thereby, reduce conjecture and maintain an accurate and timely understanding of its plans in the minds of its industry stakeholders (e.g., buyers, investors, channel members). Thus, we propose,

H4: Industry innovation is related positively to a pre-announcing firm's propensity to issue NPCs.

Extant research has primarily proposed firms in competitively hostile environments would be predisposed to not issue NPPs and, instead, be motivated to use extreme secrecy regarding its new product introduction plans (Eliashberg and Robertson 1988; Heil and Robertson, 1991; Heil and Walters, 1993; Thomas, Eliashberg, and Rymon, 1995).

However, some firms still preannounce; perhaps, motivated by mounting pressure from industry constituents (e.g., investors) regarding future product plans or to rectify inaccurate and damaging industry rumors. We propose that competitively hostile environments have, in contrast to NPPs, a positive effect on a preannouncing firm's propensity to issue NPCs.

In competitive hostile environments, NPCs allow the preannouncing firm to explain its decision to delay or cancel the new product introduction. In hostile environments, competitors would capitalize on a firm's new product delay and cancellation and cast the decision as a failure of the preannouncing firm to perform. NPCs can lessen the impact of such actions by competitors and provide the firm with the opportunity to explain the delay or cancellation, and, perhaps, reposition the decision in a more favorable light. In short, "bad" news is best explained by the preannouncing firm itself rather than by its competitors. Thus, firms would be motivated to issue NPCs.

H5: Competitive hostility is related positively to a preannouncing firm's propensity to issue NPCs.

\section{RESEARCH METHOD}

\section{SAMPLING FRAME AND SELECTION}

The sampling frame consisted of U.S. - based firms categorized as manufacturers and engaged in the development and marketing of new products. Firms with fewer than 200 employees were excluded. Smaller firms tend to have strong family influences that may skew study results (Kirpalani and MacIntosh 1980).

A subject frame of 5671 was randomly drawn from a national mailing list of executives in the position of CEO or president of their firm. Several steps were taken to promote response and minimize response bias.

- Interviews lasting more than 2 hours each were conducted with 9 CEOs to assess the viability and utility of each construct in the study and to gather language to build necessary items.

- $\quad$ The survey packet included a personalized cover letter that introduced the research, identified it as a study conducted under the guidance and authority of an academic rather than a commercial organization, highlighted its potential value to the executive, and stressed the importance of participation. Recipients were told that their responses would be both anonymous and confidential. In addition, they were offered a copy of the survey results and the research conclusions. 
- $\quad$ The survey and cover letter were pretested by 15 executives with similar responsibilities as the sample population to ensure that items were clear and convenient to answer and that the relevance of participation was evident.

- A follow-up card was sent ten days after the initial mailing to urge participation. It highlighted the relevance of the study and again offered the results. It also included the name and telephone number of a contact person if a replacement survey was needed.

The informants held the position of President, CEO, or Chairman of their respective firms and as such were heavily involved in strategy formation and thoroughly cognizant of industry issues (McKendall and Wagner 1997). The use of senior management as informants is particularly important when examining boundary-spanning activities, such as those central to our research hypotheses (Penning 1984). Finally, we chose to contact a single informant in each firm because this provides anonymity. The respondent may perceive reduced risk, which increases the likelihood of a candid response (Kohli 1989). Regarding self-report bias, previous empirical research has indicated that the areas of organizational culture, structure, and processes are relatively free of covariate inflation effects (Crampton and Wagner 1994).

Of the 5671 surveys mailed, 843 were returned marked "moved/not forwardable," "forwarding order expired," or "person no longer at company." This reduced the sample frame to 4,828; of these, 689 executives responded to the survey (a response rate of 14.7\%). Such a rate is not unexpected from high-level executives under significant time constraints and that the survey information could be considered sensitive and confidential (Calantone and Schatzel 2000). Each of these factors would produce a downward bias in responses.

Lastly, we determined the final sample that consisted only of firms that preannounced their new product introductions. The preannouncers were identified via a single item dichotomous measure that asked if, when the situation arose, their firm generally issued a public statement announcing in advance its intention to develop and introduce a new product (yes or no were offered as the only responses). Of the 689 firms responding, 211 firms indicated 'yes' and, thus, were identified as preannouncing firms and included in our final sample for hypothesis testing.

\section{Measurement Of The Antecedent And Preannouncement Propensity Constructs}

All the antecedent constructs were measured using multi-item, 7 point Likert scales anchored by strongly disagree and strongly agree. The firm's propensity to issue NPCs was measured with a single item, 7 point Likert scale, again, anchored by strongly disagree and strongly agree.

\section{Firm Information Sharing}

The firm information sharing construct describes how frequent and interactive information exchange is between the firm and other industry stakeholders. The three-item scale measuring this construct was developed using previous communication and scanning literature (e.g., O’Reilly and Roberts 1974; Miller and Friesen 1982). The items were:

- Your firm routinely gathers the opinions of customers regarding product and service needs.

- Your firm's technical personnel routinely share information about technical innovations and research trends via their participation on technical conferences and other public forums.

- Your firm values the maintenance of regular information flow about the business to employees, customers, and other industry participants.

\section{Reputation Building}

Reputation building was describes the degree to which the firm pursues a high profile leadership position within its industry. It was developed after a through review of the reputation literature (e.g., Milgrom and Roberts 1982; Weigelt and Camerer 1988). The following three items were used: 
- $\quad$ Your firm seeks to have a leadership reputation within your industry.

- Your firm seeks a significant public profile via its participation in industry activities and forums.

- $\quad$ Your firm welcomes coverage by journalists in trade magazines and the general business press.

\section{Buyer Involvement}

The buyer involvement construct the degree to which the buyers' need for knowledge and information are precursors to product trial and purchase and results from: (1) requirements to acquire information or skills to make use of the product, understand its function, or realize its benefits and (2) switching costs concerns regarding incremental expense, beyond the product, that may result from its purchase. The measure, adapted from Eliashberg and Robertson (1989) and Gatignon and Robertson (1985), contained the following three items:

- $\quad$ The purchase of your firm's new products/services requires advance planning on the part of your customer.

- The purchase of your firm's new products/services requires a significant learning experience on the part of the customer.

- $\quad$ The purchase of your firm's new products/services requires that high changeover costs are incurred by the customer (e.g., special training, obsolescence of installed capital base, extensive modifications to computer systems).

\section{Industry Innovation}

The industry innovation construct taps the degree to which the industry conditions are characterized by an emphasis on R\&D, the frequent development of truly innovative new products, technologies, and business strategies. The measure, adapted from Miller and Friesen (1982), contained the following four items:

- $\quad$ In your industry, there exists an emphasis on R\&D.

- In your industry, numerous new products or services have been introduced during the past three years.

- $\quad$ In your industry, changes in products and services have usually been dramatic.

- Most firms in your industry are bold and aggressive regarding their products, operational tactics, and business strategies.

Competitive Hostility

The competitive hostility measure, adapted (Covin and Slevin 1989), contained the following two items:

- $\quad$ The competitive environment within which your firm operates can be characterized as very stressful, exacting, hostile, and hard to keep afloat and moving forward.

- $\quad$ The competitive environment within which your firm operates can be characterized as an environment in which my firm's initiatives count for little against significant competitive pressures that exist.

\section{A Preannouncing Firm's Propensity To Issue NPCs}

A single item was used to measure this construct which taps a firm's tendency to issue a formal communication announcing its intention to delay or cancel a new product introduction.

\section{TESTING AND RESULTS}

\section{Measurement Testing And Results}

Two steps were taken to test the constructs' reliability and validity. First, we examined the reliability (internal consistency) of the measures using Cronbach's alpha coefficient and, for the two-item competitive hostility scale, its ordinary correlation (see Table 1). The reliabilities ranged from .73 to .87 and are within the generally accepted range recommended by Nunnally (1967). 
Table 1: Constructs, Measurements, and Reliabilities

\begin{tabular}{|c|c|c|}
\hline Constructs & Measurement Items & $\mathbf{a}$ \\
\hline $\begin{array}{c}\text { Firm } \\
\text { Information } \\
\text { Sharing }\end{array}$ & $\begin{array}{l}\text { 1. Your firm routinely gathers the opinions of customers regarding product and } \\
\text { service needs. } \\
\text { 2. Your firm's technical personnel routinely share information about technical } \\
\text { innovations and research trends via technical conferences and other public forums. } \\
\text { 3. Your firm values the maintenance of regular information flow about the business } \\
\text { to employees, customers, and other industry participants. }\end{array}$ & .73 \\
\hline $\begin{array}{l}\text { Reputation } \\
\text { Building }\end{array}$ & $\begin{array}{l}\text { 1. Your firm seeks a significant public profile via its participation in industry forums } \\
\text { and activities. } \\
\text { 2. Your firm seeks to have a leadership reputation within the industry. } \\
\text { 3. Your firm's management frequently issues public statements regarding their } \\
\text { opinions of industry trends and market conditions. }\end{array}$ & .74 \\
\hline $\begin{array}{c}\text { Buyer } \\
\text { Involvement }\end{array}$ & $\begin{array}{l}\text { 1. The last new product/service your firm introduced required considerable advance } \\
\text { planning on the customer's part. } \\
\text { 2. The last new product/service your firm introduced required a major learning } \\
\text { experience by the customer. } \\
\text { 3. The last new product/service your firm introduced required high changeover costs } \\
\text { for the customer. }\end{array}$ & .80 \\
\hline $\begin{array}{l}\text { Industry } \\
\text { Innovation }\end{array}$ & $\begin{array}{l}\text { 1. In your industry, there exists a strong emphasis on R\&D. } \\
\text { 2. In your industry, numerous new products or services have been introduced in the } \\
\text { past three years. } \\
\text { 3. In your industry, changes in products and services have usually been dramatic. } \\
\text { 4. Most firms in your industry are bold and aggressive regarding their products, } \\
\text { operational tactics, and business strategies. }\end{array}$ & .87 \\
\hline $\begin{array}{c}\text { Competitive } \\
\text { Hostility }\end{array}$ & $\begin{array}{l}\text { 1. The competitive environment within which your firm operates can be } \\
\text { characterized as very stressful, exacting, hostile and hard to keep afloat and } \\
\text { moving forward. } \\
\text { 2. The competitive environment within which your firm operates can be } \\
\text { characterized an environment in which my firm's initiatives and actions count for } \\
\text { little against significant competitive pressures that exist. }\end{array}$ & $\begin{array}{c}. \mathbf{6 8} \\
\text { (correlation) }\end{array}$ \\
\hline $\begin{array}{c}\text { Pre-announcing } \\
\text { Firm's } \\
\text { Propensity to } \\
\text { Issue NPCs } \\
\end{array}$ & $\begin{array}{l}\text { 1. Your firm will generally issue a formal public communication announcing its } \\
\text { intention to delay or cancel a new product introduction. }\end{array}$ & $\begin{array}{l}\text { N/A, single } \\
\text { item measure }\end{array}$ \\
\hline
\end{tabular}

Table 2: Factor Analysis Results: Communalities and Item Loadings

\begin{tabular}{|c|c|c|c|c|c|c|c|}
\hline Items & Communalities & $\begin{array}{c}\text { Factor 1 } \\
\text { Loading }\end{array}$ & $\begin{array}{c}\text { Factor 2 } \\
\text { Loading }\end{array}$ & $\begin{array}{c}\text { Factor 3 } \\
\text { Loading }\end{array}$ & $\begin{array}{c}\text { Factor 4 } \\
\text { Loading }\end{array}$ & $\begin{array}{c}\text { Factor 5 } \\
\text { Loading }\end{array}$ & $\begin{array}{c}\text { Factor 6 } \\
\text { Loading }\end{array}$ \\
\hline FIS1 & .703 & .219 & .781 & .030 & .002 & .207 & .035 \\
\hline FIS2 & .630 & .020 & .683 & .345 & .121 & .121 & -.134 \\
\hline FIS3 & .714 & .188 & .809 & .099 & .038 & .038 & .089 \\
\hline REP1 & .805 & .230 & .221 & .828 & -.107 & .054 & -.051 \\
\hline REP2 & .559 & .438 & .352 & .468 & .196 & .150 & .102 \\
\hline REP3 & .768 & .114 & .079 & .827 & .159 & .105 & .061 \\
\hline BIV1 & .740 & -.710 & .072 & .033 & .829 & .088 & .182 \\
\hline BIV2 & .750 & .094 & .009 & .072 & .946 & .117 & .080 \\
\hline BIV3 & .678 & .028 & .065 & .056 & .812 & .104 & -.013 \\
\hline INN1 & .715 & .131 & .117 & .210 & .097 & .794 & .010 \\
\hline INN2 & .735 & .160 & .066 & .009 & .090 & .827 & .114 \\
\hline INN3 & .792 & .175 & .052 & .085 & .091 & .853 & .124 \\
\hline INN4 & .728 & .009 & .143 & .076 & .098 & .831 & -.030 \\
\hline CHT1 & .756 & -.001 & .078 & .155 & .159 & .150 & .830 \\
\hline CHT2 & .774 & -.138 & -.046 & -.117 & .070 & .105 & .854 \\
\hline
\end{tabular}


Second, the construct items were factor analyzed using SPSS 11.5. A principal components analysis using varimax rotation was performed (see Table 2). The rotation converged in seven iterations and explained $71.22 \%$ of the variance. The individual item communalities all exceeded .559; therefore all items possess acceptable explanatory power. Additionally, items grouped together according to their hypothesized constructs and did not cross load with any other factors. No factor loading was below .468 indicating a reasonably degree of correlation between the items and the constructs. The results provide acceptable evidence of the five antecedent constructs' validity (Hair, Anderson, Tatham, and Black, 1995).

\section{Hypotheses Testing And Results}

After determining that the viability and validity of the proposed measurements, the hypotheses were tested using factor score regression. Factor scores are the composite measures for each of the five antecedent constructs. Hypotheses 1, 2, 3, 4, and 5 dealing with the antecedent effects on a firm's propensity to preannounce NPCs, were tested by estimating the regression equation:

$Y_{1}=b_{1} X_{1}+b_{2} X_{2}+b_{3} X_{3}+b_{4} X_{4}+b_{5} X_{5}+e_{1}$

where $Y_{I}$ denotes the firm's propensity to preannounce NPCs; $X_{I}$ through $X_{5}$ denote: (1) firm information sharing, (2) reputation building, (3) buyer involvement, (4) industry innovativeness, and (5) competitive hostility; and $e_{l}$ is the error term. The regression result was indeed significant $(\mathrm{F}=4.085, \mathrm{p} \leq .05)$ and the results are presented in Table 3.

Table 3 Strength of Hypothesized Relationships Regarding NPCs

\begin{tabular}{|l|c|c|l|}
\hline \multicolumn{1}{|c|}{ Hypothesis Description } & $\begin{array}{c}\text { Standardized } \\
\text { Parameter } \\
\text { Estimate }\end{array}$ & t-values & Conclusion \\
\hline H1: Firm information sharing is positively related to NPCs & .001 & .013 & H1 not supported \\
\hline H2: Reputation Building is positively related to NPCs & .187 & $3.145^{*}$ & H2 supported \\
\hline H3: Buyer Involvement is positively related to NPCs & .139 & $2.629^{*}$ & H3 supported \\
\hline H4: Industry innovation is positively related to NPCs & .156 & $2.629^{*}$ & H4 supported \\
\hline H5: Competitive Hostility is positively related to NPCs & .087 & 1.451 & H5 not supported \\
\hline
\end{tabular}

*p $<.05$

The findings indicate that the hypothesized effect of firm information sharing (H1) and competitive hostility (H5) on NPCs were not supported ( $b=. .018$, $\mathrm{t}$-value $=-.297 ; \mathrm{b}=.087$, $\mathrm{t}$-value $=1.451)$. However, as proposed, reputation building $(\mathrm{H} 2)$ does have a motivating effect on a pre-announcing firm's propensity to issue NPCs $(b=.187$, $t$-value $=3.145)$. The hypothesized positive impact of buyer involvement $(\mathrm{H} 3)$ was also supported $(\mathrm{b}=.139, \mathrm{t}$-value $=2.342)$. Lastly, the results indicated that, as proposed, industry innovation $(\mathrm{H} 4)(\mathrm{b}=.156, \mathrm{t}-$ value $=2.629$ ) positively influenced NPCs .

\section{CONCLUSIONS}

Our findings indicate that it is not the firm's desire to communicate in a general sense through information sharing nor its concerns regarding competitors that motivates preannouncing firms to issue NPCs. Instead, the preannouncing firm's desire to build its reputation, the innovativeness of its industry, and the degree to which buyers must make substantial pre-purchase investments are the main drivers of communication regarding changes to its new product introduction plans. As a set, these findings are particularly interesting as they indicate that the preannouncing firm's desire to reduce uncertainty, often in its own favor, underlies its decision to issue NPCs.

Previous research has indicated that a firm's emphasis on reputation building engenders the issuance of NPPs; our results indicate that this motivating effect carries through to the preannouncing firm's use of NPCs as well. NPCs provide the preannouncing firm with the means to effective and efficiently provide updates to its new product plans and explicate reasons for its delay or cancellation. Thus NPCs provide preannouncer's that emphasize 
reputation building with the opportunity to demonstrate their commitment to the new product development process such that when changes to their planned new product introductions occur they feel compelled to inform their stakeholders of the decision and rationale surrounding it.

The recent business scandals, such as those experienced at Enron and Tyco, have resulted in an increased demand for corporate transparency and information disclosure. Firms that communicate effectively in an ongoing manner - giving the "bad", as well as, the "good" news regarding their new product plans - are, in fact, responding to this increased demand for information by industry stakeholders. The reputation building firm's willingness to provide continuous communication regarding its new product introduction plans signals to its stakeholders a desire to be open and honest regarding its plans; in short, to be recognized as a firm worthy of doing business with ... a firm to be 'trusted'.

Additionally, the results indicate industry innovation motivates preannouncing firms to issue NPCs. Frequent and discontinuous product innovations characterize highly innovative industries and, therefore, industry innovation may serve as a proxy for industry uncertainty. Highly uncertain environments can deter the adoption of a new product and slow its diffusion (Carpenter and Nakamoto 1989); thus, a preannouncing firm would be motivated to reduce industry uncertainty by providing continuous updates regarding the status of its new product plans.

Lastly, the findings provide that buyer involvement is positively related to a preannouncing firms' propensity to issue NPCs; that is, a pre-announcer recognizes and responds to the greater switching costs (both informational and economic) associated with involved purchase decisions by issuing NPCs. As previously discussed, extant research has indicated that buyer involvement motivates the issuance of NPPs; coupled with this finding, the notion of continuous communication regarding the introduction of new products, inclusive of any delays and cancellations is, again, highlighted.

In conclusion, this study's main objective was to examine what factors motivate firms that preannounce their new products to announce changes to their status (i.e., delays or cancellations). The results indicate that as a communication tool NPCs provide firms with the means to reduce uncertainty in the minds of various industry stakeholders. These linkages point to the use of NPCs as a means for the preannouncing firm to provide continuous information regarding its new product introduction plan - even if the 'news' is bad, as in the case of delays or cancellations. This emphasis on continuous communication indicates preannouncers that issue NPCs seek to establish on-going and routine communication with their stakeholders regarding their new product intentions and provide them with clear insight and understanding as to those plans; in short, they value disclosure and transparent communication.

For managers, the study's findings point to further emphasis on continuous communication regarding their firm's new product plans especially in environments characterized by higher degrees of product innovation and involved purchase decisions. Additionally, firms that seek to be recognized publicly recognized, based on their reputation as an industry leader, should make a through executive review of their communication practices and policies regarding their new product introduction plans.

\section{SUGGESTIONS FOR FUTURE RESEARCH}

However, further research is needed to determine the best means to issue effective NPCs; the when, what, by whom and how questions associated with the issuance of information regarding changes in the status of new product introductions. In short, a normative framework regarding NPCs requires further investigation and explication. Additionally, some possible limitations to this study should also be noted. First, several new constructs were developed. Testing supported their validity, but more research is needed to provide conclusive and generalizable evidence regarding these factors. Second, the response rate of $14.7 \%$, although acceptable, is a possible limitation, and other studies are needed to replicate the findings. Finally, the constructs were examined with perceptual measures, which are subject to the bias of respondents. Again, further studies are needed to improve the generalizability of the results. 


\section{REFERENCES}

1. Bayus, B., S. Jain, and A. Rao. 2001. Truth or Consequences: An Analysis of Vaporware and New Product Announcements. Journal of Marketing Research 38(1): 3-13.

2. Carpenter, G. and K. Nakamoto. 1989. Consumer Preference Formation and Pioneering Advantage. Journal of Marketing Research, 26(3) : 215-298.

3. Calantone, R. and K. Schatzel. 2000. Strategic Foretelling: Communication-Based Antecedents of a Firm's Preannouncement Behavior. Journal of Marketing 64(1): 17-30.

4. Chaney, P., T. Devinney, and R. Winer (1991). The Impact of New Product Introductions on the Market Value of Firms', Journal of Business, 64(4), 573-610.

5. Covin, J., and D. Slevin (1989). Strategic Management of Small Firms in Hostile and Benign Environments', Strategic Management Journal, 32, 75-87.

6. Crampton, S., and J. Wagner III. 1994. Percept-Percept Inflation in Microorganizational Research: An Investigation of Prevalence and Effect. Journal of Applied Psychology 79(1): 67-76.

7. Eddy, A., and G. Saunders (1980). New Product Preannouncements and Stock Prices, Decision Sciences, 11, 90-97.

8. Eliashberg, J. and T. Robertson (1988). New Product Pre-announcing Behavior: A Market Signaling Study, Journal of Marketing Research, 25, 282-292.

9. $\quad$ Farrell, J., and G. Saloner (1986). 'Installed Base and Compatibility: Innovation, Product Preannouncements, and Predatio, The American Economic Review, 76(5), 940-955.

10. Gatignon, H., and T. Robertson (1985). A Propositional Inventory of New Diffusion Research, Journal of Consumer Research, 11, 849-867.

11. Heil, O., and T. Robertson (1991), Towards a Theory of Competitive Market Signaling: A Research Agenda, Strategic Management Journal, 12, 403-418.

12. Heil, O., and R. Walters (1993). 'Explaining Competitive Reactions to New Products: An Empirical Signaling Study, Journal of Product Innovation Management, 10, 53-65.

13. Hise, R., L. O'Neal, A. Parasuraman, and J. McNeal (1990). Marketing/R\&D interaction In new product development: Implications for new product success rates, Journal of Product Innovation Management, 7 , $142-155$.

14. Kirpalani, V., and N. MacIntosh. 1980. International Marketing Effectiveness of Technology-Oriented Small Firms. Journal of International Business Studies 11: 81-90.

15. Kohli, A. 1989. Determinants of Influence in Organizational Buying: A Contingency Approach. Journal of Marketing 53(3): 50-65.

16. Kreps, D., and R. Wilson. 1982. Reputation and Imperfect Information. Journal of Economic Theory 27(2): 863-894.

17. Lane, V., and R. Jacobsen (1995). Stock Market Reactions to Brand Extension Announcements: The Effects of Brand Attitude and Familiarity, Journal of Marketing, 59, 63-77.

18. Lilly, B., and R. Walters (1997). Toward a Model of New Product Preannouncement Timing, Journal of Product Innovation Management, 14(1), 4-20.

19. Mahajan, V., E. Muller, and F. Bass (1990). New Product Diffusion Models in Marketing: A Review and Directions for Research, Journal of Marketing, 54, 1-26.

20. McKendall, M.A., and J.A Wagner III (1997). Motives, Opportunity, Choice and Corporate Illegality, Organizational Science, 8(5), 1-24.

21. Miller, D., and P. Friesen (1982). Innovation In Conservative and Entrepreneurial Firms: Two Models of Strategic Momentum, Strategic Management Journal, 3, 1-25.

22. Nunnally, J. C. 1967, Psychometric Theory, McGraw-Hill, New York.

23. Penning, J.M. 1984. Coordination between Strategically Interdependent Organizations. Handbook of Organizational Design. P.C. Nystrom and W.C. Starbuck, eds. Amsterdam Elsevier : 433-476.

24. Prabhu, J., and D. Stewart. 2001. Signaling Strategies in Competitive Interaction: Building Reputations and Hiding the Truth. Journal of Marketing Research, 38(1): 62-72.

25. Rabino, S., and T. Moore. 1989. Managing New-Product Announcements in The Computer Industry. Industrial Marketing Management 18(1) : 35-43. 
26. Robertson, T., J. Eliashberg, and T. Rymon (1995). New Product Announcement Signals and Incumbent Reactions, Journal of Marketing, 59,1-15.

27. Rumelt, R. (1987). Theory, Strategy, and Entrepreneurship, The Competitive Challenge: Strategies for Industrial Innovation and Renewal, Ballinger Publishing, Cambridge, MA.

28. Spence, A.(1974). Market Signaling. Harvard University Press, Cambridge, MA.

29. Schatzel, K., R. Calantone, and C. Droge. 2001. Beyond the Firm's Initial Declaration: Are Preannouncements of New Product Introductions and Withdrawals Alike? The Journal of Product Innovation Management 18(2): 82-112

30. Schatzel, K., C. Droge and R. Calantone. 2003. Strategic Channel Activity Preannouncements: An Exploratory Investigation of Antecedent Effects. Journal of Business Research 56(12): 3-28.

31. Weigelt, K., and C. Camerer. 1988. Reputation and Corporate Strategy: A Review of Recent Theory and Application. Strategic Management Journal 9(5): 443-454.

\section{NOTES}

